\title{
Classic galactosemia
}

Citation for published version (APA):

Haskovic, M. (2020). Classic galactosemia: natural history and new treatment approaches. [Doctoral Thesis, Maastricht University]. ProefschriftMaken. https://doi.org/10.26481/dis.20201002mh

Document status and date:

Published: 01/01/2020

DOI:

10.26481/dis.20201002mh

Document Version:

Publisher's PDF, also known as Version of record

\section{Please check the document version of this publication:}

- A submitted manuscript is the version of the article upon submission and before peer-review. There can be important differences between the submitted version and the official published version of record.

People interested in the research are advised to contact the author for the final version of the publication, or visit the DOI to the publisher's website.

- The final author version and the galley proof are versions of the publication after peer review.

- The final published version features the final layout of the paper including the volume, issue and page numbers.

Link to publication

\footnotetext{
General rights rights.

- You may freely distribute the URL identifying the publication in the public portal. please follow below link for the End User Agreement:

www.umlib.nl/taverne-license

Take down policy

If you believe that this document breaches copyright please contact us at:

repository@maastrichtuniversity.nl

providing details and we will investigate your claim.
}

Copyright and moral rights for the publications made accessible in the public portal are retained by the authors and/or other copyright owners and it is a condition of accessing publications that users recognise and abide by the legal requirements associated with these

- Users may download and print one copy of any publication from the public portal for the purpose of private study or research.

- You may not further distribute the material or use it for any profit-making activity or commercial gain

If the publication is distributed under the terms of Article $25 \mathrm{fa}$ of the Dutch Copyright Act, indicated by the "Taverne" license above, 
Summary 
Classic galactosemia is a rare metabolic disease affecting galactose metabolism, caused by severe deficiency of galactose-1-phosphate uridylyltransferase (GALT) enzyme activity. The standard of care, a life-long galactose restricted diet, although live saving in the neonatal period, fails to prevent chronically debilitating complications mainly affecting brain and gonads. In chapter $\mathbf{1}$, we elaborate on classic galactosemia, its pathophysiology and complications, and introduce the objectives of this dissertation. The objectives were to delineate the natural history of classic galactosemia based on a large patient cohort, provide new insight into the pathophysiological mechanisms and explore possible treatment strategies, by combining clinical and basic research.

Close collaboration among healthcare providers, researchers and patients' associations is crucial in order to move classic galactosemia research forward and improve patient outcomes. Towards this aim, in 2012, the international galactosemia network (GalNet), including professionals from nineteen European countries, Australia and the United States, was founded by our group, supported by the Dutch and European galactosemia patients' associations. The GalNet has successfully developed and implemented the GalNet patient registry, coordinated by the MUMC+. This registry contains data from >600 patients with GALT (classic galactosemia), GALK and GALE deficiency. Chapter 2 describes the natural history of classic galactosemia, based on the hitherto largest cohort of patients ( $n=509$ ), from 15 countries and 32 centers. The data, collected from 2014 to 2018, revealed that most patients experience neonatal illness (79.8\%). Despite dietary treatment, $85.0 \%$ of patients present with brain complications, $79.7 \%$ of female patients suffer from primary ovarian insufficiency and $26.5 \%$ of patients exhibit a slightly diminished bone mineral density. Importantly, predictive factors influencing the phenotype include newborn screening, age of onset of dietary treatment, strictness of the diet and GALT enzyme activity.

In the past decades, a myriad of research has taken place to gain more insight on the complex pathophysiology of classic galactosemia. As expertise center for galactosemia, our group is involved in many collaborative studies and is consulted regularly about clinical and research questions. Throughout the years it has become clear that there was a void knowledge regarding the pathophysiology, that urged a comprehensive overview of the hitherto performed studies. We conducted a systematic review of the hitherto available literature in cellular and animal models, providing important information regarding the pathophysiology and targets for treatment in classic galactosemia, presented in chapter 3. Important outcomes of this systematic review are that Gal-1-P is not the sole pathogenic factor responsible for the observed clinical phenotype, but that other mechanisms including toxic accumulation of galactose metabolites, glycosylation abnormalities, altered signaling pathways, endoplasmic reticulum (ER) stress, oxidative stress and structural and functional impairments of GALT, contribute as well. Systematically reviewing the literature showed 
inconsistent results regarding the uridine diphosphate-galactose (UDP-Gal) and UDP-Glc levels measured in patient cell lines. Alterations in these nucleotide sugars have been hypothesized to play a key role in the observed glycosylation abnormalities. In order to gain more insight into UDP-Gal, UDPGlc but also other nucleotide sugar levels in classic galactosemia, we have conducted a pioneer study in our recently developed zebrafish model. This model mimics the human phenotype at biochemical and clinical levels and allows studies throughout development and in tissues. In chapter $\mathbf{4}$ we, for the first time, characterize the complete nucleotide sugars profiles in our galt knockout zebrafish, throughout development and in tissues of damage, brain and gonads. We report stage- and tissuespecific nucleotide sugar profiles in zebrafish, which are similar between wildtype and galt knockout zebrafish. Our study at different developmental stages and in target tissues of damage does not support a role for UDP-Gal or UDP-Glc abnormalities as a key pathogenic factor in classic galactosemia. This shifts the paradigm regarding the underlying pathophysiological mechanism(s) of the observed glycosylation abnormalities.

Hitherto efforts to develop new, effective therapies are focused on the rescue of GALT activity/stability as well as on influencing the phenomena cascade elicited by GALT deficiency. In this dissertation, we evaluate two different treatment approaches that directly address GALT. First, in chapter 5, we explore the therapeutic potential of human GALT messenger RNA (mRNA) in our galt knockout zebrafish model at early stage of development. The mRNA-based approach is emerging as a treatment modality that can treat a variety of diseases by restoring the respective defective protein. Notably, in opposition to gene therapy, the risk of insertional mutagenesis is low, since mRNA does not transit to the nucleus. We show that administration of both naked and lipid nanoparticle (LNP)-packaged human GALT mRNA to galt knockout zebrafish lead to functional GALT. This non-mutation-specific approach holds great promise for future research and, eventually, clinical implementation of mRNA-based therapy.

Disease-associated variants affect protein folding, resulting in lower enzymatic activity. Previous studies have suggested the potential of pharmacological/chemical chaperones as therapeutic strategy to rescue variant proteins. Studies in a prokaryotic model showed a beneficial effect of arginine, a chemical chaperone, for several GALT variants. In chapter 6, we evaluate the therapeutic potential of arginine in four patients with the most prevalent variation in the western population, c.563A>G (p.GIn188Arg) homozygosity. Our study shows that arginine is not therapeutically beneficial in patients homozygous for p.Gln188Arg. These results do not preclude that arginine could be beneficial in patients with other GALT variations. Patients homozygous for p.Gln188Arg might benefit from a different, non-mutation-specific treatment approach (e.g. mRNA-based approach). 
The gonads represent one of the major target organs in classic galactosemia. In many female patients, primary ovarian insufficiency (POI) and subsequent subfertility are reported. Despite that spontaneous pregnancies have been reported, subfertility issues entail a great burden for patients and their families. Recommendations from a multidisciplinary team of experts lead by our team, regarding fertility preservation are available, aiming to improve patient care. One of the fertility preservation options that is often brought up by patients/families is intra-familial oocyte donation, most often from mother or sister to the patient. This option raises several important medical, ethical and societal concerns, which prompt us to explore the views and opinions on these aspects from different groups involved (patient, family members, healthcare professionals) in chapter 7. Based on this qualitative study, we provide recommendations for healthcare professionals that are involved in the care of female classic galactosemia patients who suffer from POI and subsequent subfertility, when considering the possibility of intra-familial oocyte donation.

Finally, in chapter 8, results obtained in this dissertation are discussed and future research prospective are outlined, towards the ultimate aim of improving the care for galactosemia patients. 



\section{Samenvatting}


Klassieke galactosemie is een zeldzame metabole aandoening van het galactose metabolisme, veroorzaakt door ernstige deficiëntie van het enzym galactose-1-fosfaat uridylyltransferase (GALT). De huidige behandelstandaard, een levenslang galactose-bepekt dieet, kan de ernstige chronische complicaties die vooral het brein en de gonaden treffen niet voorkomen. In hoofdstuk 1 gaan we dieper in op de pathofysiologie en complicaties van klassieke galactosemie, en introduceren we de doelstellingen van dit proefschrift. De doelstellingen waren om het natuurlijk beloop van klassieke galactosemie te beschrijven op basis van een grote patiëntengroep, om nieuwe inzichten in de pathofysiologische mechanismen te verkrijgen en mogelijke behandelstrategieën te evalueren door klinisch en fundamenteel onderzoek te combineren.

Samenwerking tussen zorgverleners, onderzoekers en patiëntenverenigingen is cruciaal om het onderzoek naar klassieke galactosemie naar een hoger niveau te tillen en de zorg voor patiënten te verbeteren. Om dit doel te bereiken, werd in 2012 het internationale galactosemie netwerk (GalNet), met professionals uit negentien Europese landen, Australië en de Verenigde Staten, opgericht door onze onderzoeksgroep, ondersteund door de Nederlandse en Europese patiëntenverenigingen voor galactosemie. Het GalNet heeft het GalNet patiënten register ontwikkeld en geïmplementeerd, welke gecoördineerd wordt vanuit het MUMC+. Dit register bevat gegevens van $>600$ patiënten met GALT (klassieke galactosemie), GALK en GALE deficiëntie. Hoofdstuk 2 beschrijft het natuurlijk beloop van klassieke galactosemie, gebaseerd op het tot nu toe grootste patiënten cohort ( $n=509)$, uit 15 landen en 32 centra. De data, verzameld van 2014 tot 2018, toonden dat de meeste patiënten $(79,8 \%)$ neonatale complicaties hebben. Ondanks het galactose-beperkte dieet, ontwikkelt $85,0 \%$ van de patiënten beperkingen die het brein treffen, lijdt $79,7 \%$ van de vrouwelijke patiënten aan primaire ovariële insufficiëntie en heeft $26,5 \%$ van de patiënten een licht verminderde botmineraaldichtheid. Factoren die het fenotype beïnvloeden zijn de hielprik screening, leeftijd bij aanvang van het dieet, striktheid van het dieet en enzymactiviteit van GALT.

In de afgelopen decennia zijn verschillende onderzoeken uitgevoerd met het doel om meer inzicht te verkrijgen in de complexe pathofysiologie van klassieke galactosemie. Als expertisecentrum voor galactosemie is onze groep betrokken bij vele collaboratieve studies, en worden wij regelmatig geraadpleegd over klinische en onderzoeksvragen. De afgelopen jaren is gebleken dat er lacunes bestaan in onze kennis betreffende de pathofysiologie, wat de vraag naar een uitgebreid overzicht van de tot nu toe uitgevoerde onderzoeken opriep. In hoofdstuk 3 presenteren we ons systematische review van de tot nu toe beschikbare literatuur in cel- en diermodellen, waaruit belangrijke informatie met betrekking tot de pathofysiologie en mogelijke aangrijpingspunten voor behandeling van klassieke galactosemie wordt verkregen. Belangrijke resultaten van deze review zijn dat Gal-1-P niet de enige pathogene factor is die verantwoordelijk is voor het waargenomen klinische fenotype, maar dat ook 
andere mechanismen hieraan bijdragen, waaronder toxische accumulatie van galactosemetabolieten, afwijkingen in de glycosylering, veranderde signaleringsroutes, endoplasmatisch reticulum (ER) stress, oxidatieve stress en structurele en functionele beperkingen van GALT. Het systematisch beoordelen van de literatuur toonde tegenstrijdige resultaten met betrekking tot de nucleotide suikers uridinedifosfaat-galactose (UDP-Gal) en UDP-glactose (GIc) levels gemeten in cellijnen afkomstig van patiënten. Veranderingen in deze nucleotide suikers zouden een sleutelrol spelen in de waargenomen afwijkingen in de glycosylering. Om meer inzicht te krijgen in UDP-Gal, UDP-Glc, maar ook andere nucleotide suiker profielen in klassieke galactosemie, hebben we een studie gedaan in ons recent ontwikkelde zebravismodel. Dit model bootst het menselijke fenotype na, op biochemisch én klinisch niveau, en maakt zowel studies tijdens de ontwikkeling als in weefsels mogelijk. In hoofdstuk 4 karakteriseren we voor het eerst de volledige nucleotide suiker profielen in onze galt knockout zebravis, gedurende de ontwikkeling en in weefsels (het brein en de gonaden). We rapporteren ontwikkelingsstadium- en weefselspecifieke nucleotide suiker profielen, die vergelijkbaar zijn tussen wildtype en galt knockout zebravissen. Onze studie in verschillende ontwikkelingsstadia en in de weefsels van schade laat geen rol zien voor UDP-Gal of UDP-Glc afwijkingen als een belangrijke pathogene factor in klassieke galactosemie. Dit verandert het paradigma met betrekking tot de onderliggende pathofysiologische mechanismen van de waargenomen afwijkingen in de glycosylering.

Tot dusver zijn inspanningen om nieuwe, effectieve therapieën te ontwikkelen, gericht op zowel het verbeteren van de GALT-activiteit/stabiliteit als op het beïnvloeden van de cascade die ontstaat ten gevolge van GALT deficiëntie. In dit proefschrift evalueren we twee verschillende behandel strategieën die direct effect hebben op GALT. In hoofdstuk 5 onderzoeken we het therapeutisch effect van humaan GALT messenger RNA (mRNA) in ons galt knockout zebravismodel in een vroeg ontwikkelingsstadium. De op mRNA gebaseerde benadering is in opkomst als een behandelmodaliteit die verschillende ziekten zou kunnen behandelen door het respectievelijke defecte eiwit te herstellen. In tegenstelling tot gentherapie is het risico op insertie-mutagenese laag, omdat mRNA niet de kern binnentreedt. We laten zien dat toediening van humaan GALT mRNA, zowel 'onverpakt' als verpakt in een lipide nano partikel (LNP), aan galt knockout zebravissen, leidt tot functioneel GALT. Deze benadering, die niet mutatie specifiek is, is veelbelovend voor toekomstig onderzoek en, uiteindelijk, klinische implementatie van op mRNA gebaseerde therapie.

Ziekte gerelateerde varianten beïnvloeden de eiwitvouwing, wat resulteert in een lagere enzym activiteit. Verschillende studies hebben het potentieel van farmacologische/chemische chaperonnes gesuggereerd als therapeutische strategie om varianteiwitten te herstellen. Studies in een prokaryotisch model lieten een gunstig effect van arginine (een chemische chaperonne) zien voor verschillende GALT varianten. In hoofdstuk 6 evalueren we het therapeutisch effect van arginine in 
vier patiënten die homozygoot zijn voor met de meest voorkomende variatie in de westerse populatie, c.563A> G (p.GIn188Arg). Onze studie toont aan dat arginine niet therapeutisch effectief is in patiënten die homozygoot zijn voor p.GIn188Arg. Deze resultaten sluiten niet uit dat arginine gunstig zou kunnen zijn in patiënten met andere GALT variaties. Patiënten die homozygoot zijn voor p.GIn188Arg kunnen baat hebben bij een andere, niet mutatie specifieke behandel strategie (bv. op mRNA gebaseerde therapie).

De gonaden zijn een van de belangrijkste target organen van schade in klassieke galactosemie. Veel vrouwelijke patiënten lijden aan primaire ovariële insufficiëntie (POI) en als gevolg hiervan aan subfertiliteit. Ondanks het feit dat spontane zwangerschappen zijn gerapporteerd, brengen vruchtbaarheidsproblemen een grote last met zich mee voor patiënten en hun families. Er zijn aanbevelingen met betrekking tot het behoud van vruchtbaarheid beschikbaar, geschreven door een multidisciplinair team van experts onder leiding van onze onderzoeksgroep, met als doel om de patiëntenzorg te verbeteren. Een van de opties voor het behoud van vruchtbaarheid die vaak door patiënten/families naar voren wordt gebracht, is intra-familiale eiceldonatie, meestal van moeder of zus aan de patiënt. Deze optie roept belangrijke medische, ethische en maatschappelijke vragen op, welke ons ertoe aanzetten om de opvattingen en meningen van verschillende betrokken groepen (patiënten, familieleden, professionals) te onderzoeken, gepresenteerd in hoofdstuk 7. Op basis van deze kwalitatieve studie geven we aanbevelingen/overwegingen, bedoeld voor professionals die betrokken zijn bij de zorg voor vrouwelijke klassieke galactosemie patiënten die lijden aan POI en subfertiliteit, wanneer zij de mogelijkheid van intra-familiale eiceldonatie overwegen.

Ten slotte worden in hoofdstuk $\mathbf{8}$ de resultaten van dit proefschrift besproken en worden toekomstige onderzoeksperspectieven geschetst, met het oog op het uiteindelijke doel om de zorg voor galactosemie patiënten te verbeteren. 